\title{
Multiple Abnormal Unerupted Mandibular Permanent Molar Teeth: A Case Report
}

\author{
Molares Mandibulares Anormales No-Erupcionados Múltiples: Reporte de un Caso
}

"Umit Karacayli \& **Nuket Gocmen-Mas

KARACAYLI, U. \& GOCMEN-MAS, N. Multiple abnormal unerupted mandibular permanent molar teeth: a case report. Int. J. Morphol., 27(1):65-68, 2009.

SUMMARY: Abnormal multiply unerupted permanent molars have long received the attention of anatomists and maxillofacial surgeons besides the other developmental teeth anomalies. This paper presents a clinical case of a 23-year-old male patient who was admitted to the department of maxillofacial surgery in faculty of dentistry in Gulhane Medical School with a six month history of pain at the rest position and during chewing and also tender on his right corpus of mandible. The impaction which resulted in eruption failure and anatomical dislocation of the normally developed three mandibular molar teeth was found. It was defined facial asymmetry on his right side in extra-oral examination. Diagnosis of multiple abnormal unerupted mandibular molar teeth was confirmed by panoramic and 3D CT images. The unerupted inverted tooth was the third molar which is positioned to basis of the mandible on the right side. In the other side, the first molar was placed on basis of mandible and located distoangulary. The second molar was located on middle of the left corpus mandible vertically. And also, the third molar was erupted mesioangulary. The arch-length was evaluated by the oral surgeon. Mesiodistal distance between the teeth was to be sufficient. Causes of impacted permanent teeth might have been influenced by local factors such as prolonged deciduous tooth retention, malposed tooth germs, but not causing arch-length deficiency and supernumerary teeth. Abnormalities such as those reported in the present case are significant during maxillofacial surgery.

KEY WORDS: Malposed molar teeth; Permanent teeth, Uneruption; Abnormality.

\section{INTRODUCTION}

The anatomy and embryological development of the molar teeth are of importance for clinicians. Multiply abnormal unerupted permanent mandibular molars have also long received the attention of anatomists and oral surgeons during surgical approaches. Normally, the molars whose size decreases distally, each has rectangular occlusal surface with four or five cusps in lower jaw. The lower first molar has three buccal and two lingual cusps on its rectangular occlusal surface, the smallest being distobuccal. The cusps of this tooth are all separated by fissures, it has two widely separated roots as mesial and distal. The smaller lower second molar is like the first but usually lacks the distobuccal cusp and its two roots are closer together. The lower third molar is smaller still and like the upper third molar it is variable in form. Some variations in the form of teeth, being characteristic of race, are of anthropological and forensic interest (Williams et al., 1995). Despite to involving unerupted permanent teeth, primary failure of tooth eruption involving primary teeth was declared by many authors (Hayashi-Sakai et al., 2005; Ostuka et al., 2001). They claimed that primary tooth impaction is usually associated with defect in the development and eruption of the permanent successors (Ostuka et al.). Secondary retention refers to the cessation of eruption of a tooth after emergence neither because of a physical barrier in the path of eruption nor as a result of an unusual position (Raghoebar et al., 1990, 1991).

Normally, eruption of the first permanent lower molar tooth is 6-7 years, the second molar is 11-13 years, and the third molar is 17-21 years (Williams et al.). As the jaws lengthen the dental lamina grows posteriorly from the distal aspect of the second deciduous molar germ as a solid cord of epithelium, not connected with the surface. From the deep border of this "burrowing" lamina, buds for the three permanent molars develop in mesiodistal sequence, the first molar bud appearing in the 16-week fetus, the second at about

* Gulhane Medical School Department of Oral and Maxillofacial Surgery, Ankara, TURKEY.
** Kocatepe University School of Medicine Department of Anatomy, Afyonkarahisar, TURKEY. 
one year and the third at five years. Each bud is initiated in the ramus of the lower jaw but, with progressive resorption of the anterior border of coronoid process, they come to occupy the body of the mandible. From each deciduous tooth germ at its bell stage a lingual successional lamina grows from the site of continuity between outer and enamel epithelium and dental lamina. Each grows down into mesenchyme lingual to a deciduous tooth and from its end a bud develops for a permanent successor, which becomes surrounded by its own follicle and crypt. The follicle maintains fibrous continuity with the lamina propria of oral mucosa by "gubernacular cords", whose original positions are visible in young skulls as "gubernacular canals". Information on the development of teeth and their emergence into the oral cavity is significant in clinical or surgical practice and in forensic medicine and archaeology as well (Miloro, 2004; Williams et al.).

\section{CASE REPORT}

This report presents a clinical case of a 23-year-old male patient who was admitted to the Department of Maxillofacial Surgery in Faculty of Dentistry in Gulhane Medical School, with a six month history of pain at the rest position and during chewing and also tender on his right corpus of mandible. The dislocated molar teeth were defined during routine examination. History of systemic and embryological diseases, dysplasic syndromes and trauma in the facial region were consulted by the general physician.
Diagnosis of multiple abnormal unerupted mandibular molar teeth was confirmed by 3D CT (Figs.1a,c) and panoramic (Fig.1b). The arch-length was evaluated by the oral surgeon. The findings were photographed and documented. A written informed consent was obtained for case report and disclosure of photographs, radiographs and CT scans for scientific purposes.

It was found the impaction resulted in eruption failure and anatomical dislocation of the normally developed three mandibular molar teeth. One of the unerupted inverted teeth was the right third molar (LR8), which was positioned to basis of the mandible. On the left side, the first mandibular molar (LL6) was located on the basis of mandible distoangulary and the second molar (LL7) was located on middle of the corpus of the mandible vertically. And also, the third molar (LL8) was erupted mesioangulary. Mesiodistal distance between the teeth was to be sufficient. It was defined both facial asymmetry and swelling on the right side due to impacted invert third molar tooth in basis of ramus mandible during extra oral examination, and also mandibular asymmetry in 3D CT on the right side (Fig.2). The patient's family did not have a similar complaint. Clinical examination did not reveal systemic and embryologic diseases and trauma in the facial region. A general physician was consulted who confirmed that there were no associated dysplasic syndromes. Extra oral surgical approach was planned for LR8 and LL6 because of abnormal positioning of the teeth in basis of the mandible. Surgical approach was not accepted by the patient due to aesthetical reason.

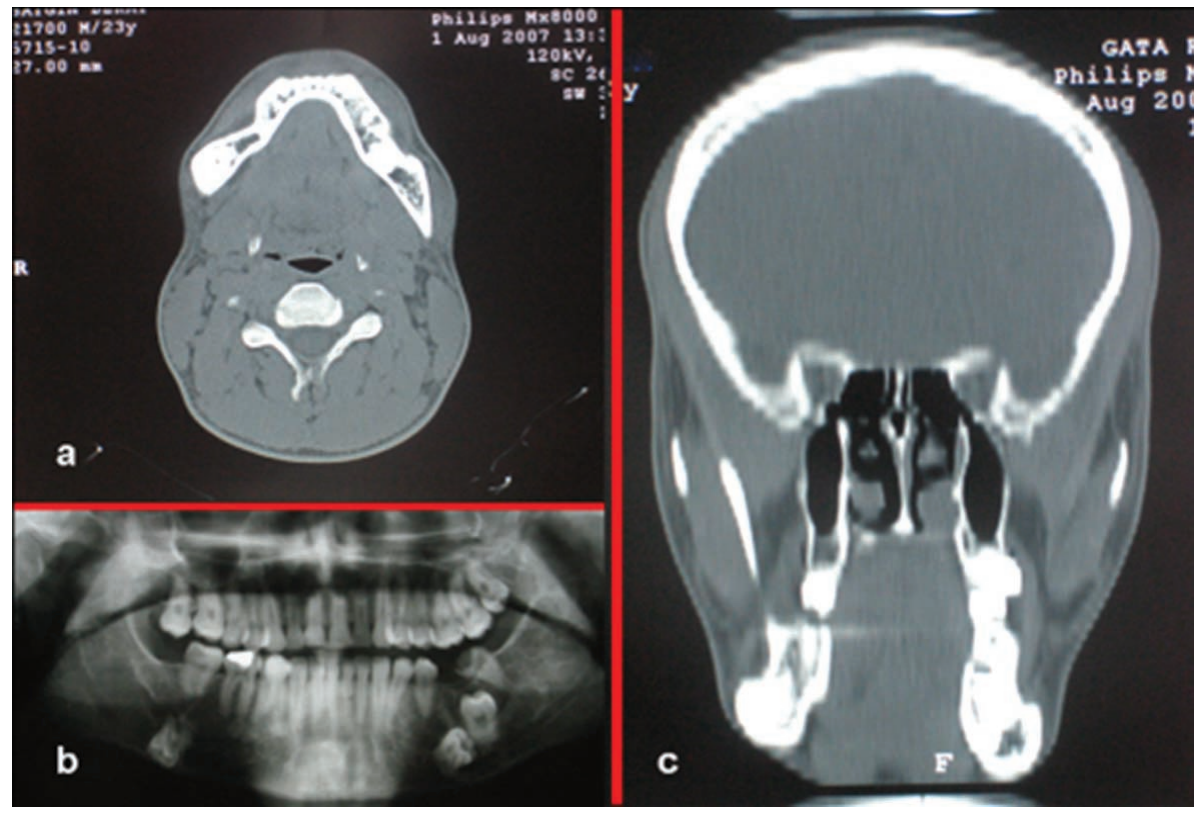

Fig. 1. (a) Transvers CT image of the assymetric mandible. (b) Panoramic radiograph of the whole dentition of upper and lower jaws. In the mandible the right third molar and the left first and second molar teeth have been unerupted. (c) Assymetric right corpus of the mandible has been indicated by the arrow. 


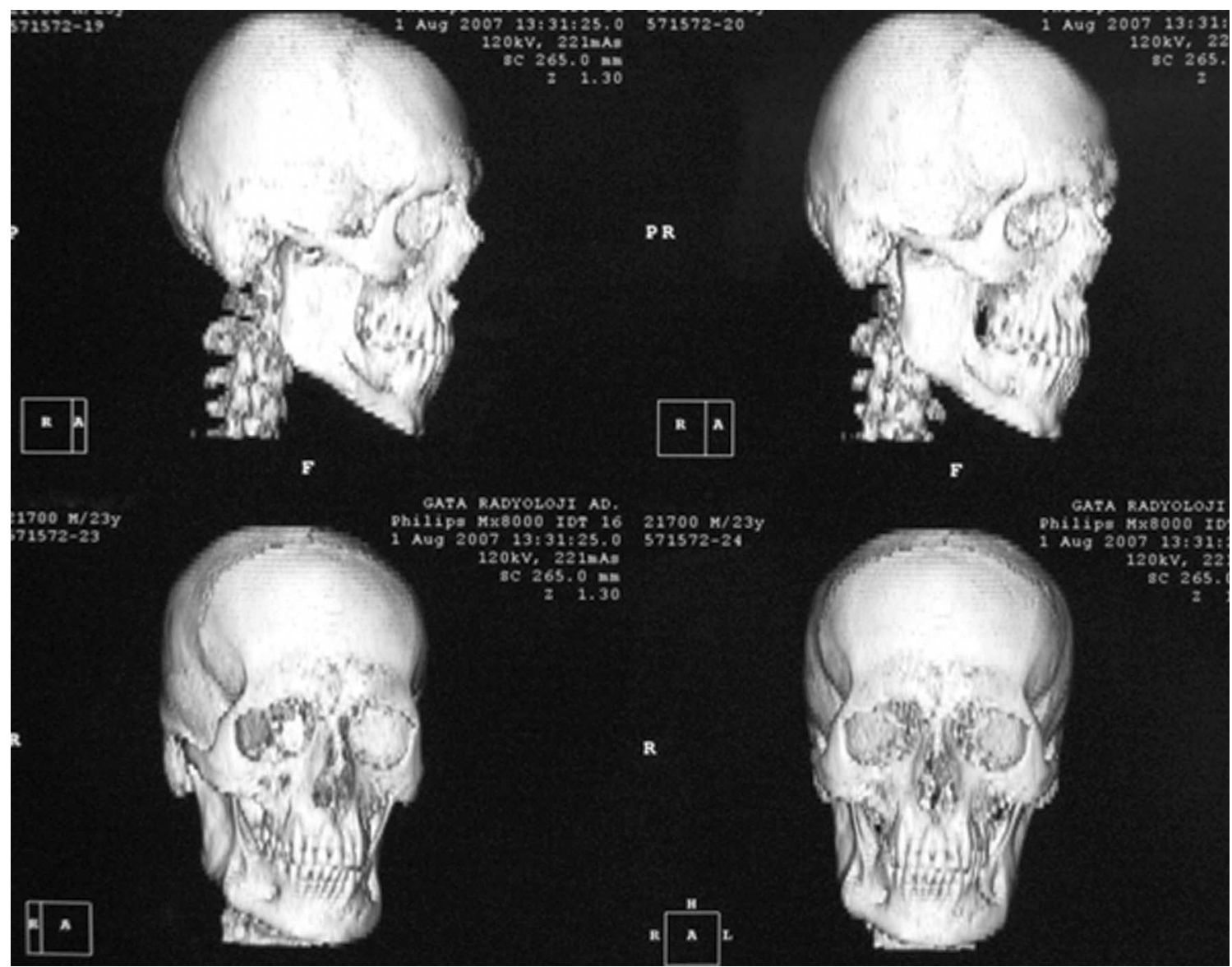

Fig.2: 3D CT image of assymetric right ramus of the mandible. The location of the unerupted teeth have been shown.

\section{DISCUSSION}

Many authors concerning the classification and the incidence of impacted teeth and specifically premolars but not mostly molars are reviewed. In literature there is a little and limited knowledge about presence of unusual or multiply unerupted molars. For this reason we aimed to decelerate multiple abnormal unerupted mandibular permanent molar teeth as a variant.

According to the literature, the canine tooth was the most frequent non-third molar impaction identified, followed by premolars and second molars (Ahlqwist \& Gröndahl, 1991; Miloro). Thilander \& Myrberg (1973) found a 5.4\% prevalence of impacted teeth excluding third molars. Dachi and Howell found the incidence of impacted canines in the maxilla to be $0.92 \%$ and of other non-third molar teeth to be $0.38 \%$. Impactions of first molars and incisors are relatively uncommon (Raghoebar et al., 1990; 1991). Systemic factors, such as cleidocranial dysplasia, endocrine deficiency, febrile disease, Down Syndrome and irradiation, other systemic factors or/and local factors such as prolonged deciduous tooth retention, malposed tooth germs, arch-length deficiency, supernumerary teeth, odontogenic tumors abnormal eruption path and cleft lip and palate may influence impaction of permanent teeth (Jacoby et al., 1983; Raghoebar et al., 1991; Moyres, 1998; Miloro). The impaction of first molars is often diagnosed as ectopic eruption, whereas impaction of second molars is usually associated with arch-length deficiency (Raghoebar et al., 1991). Normally, the gubernacular canals are said to guide erupting permanent teeth into their correct positions (Williams et al.). In the present case, the causes of impacted permanent teeth might have been influenced by local factors, such as prolonged deciduous tooth retention, malposed tooth germs, but not arch-length deficiency and supernumerary. Causes of impacted permanent teeth might have been influenced by local factors, such as prolonged deciduous tooth retention, malposed tooth germs (Miloro), but not causing arch-length deficiency and supernumerary teeth. We think that the molar teeth of the present case may 
not follow the correct gabernacular canals guide as a cause of this the unerupted teeth inverts uncommon position.

Unerupted molars may exist in some cases. Dentists should keep this in mind when examining the oral cavity, both clinically and radiographically when multiply unerupted molars are found.
The firstly reported case and the data may support the literature about presence of the multiple abnormal unerupted mandibular molar teeth. Detailed information about unerupted molar teeth is of importance to eliminate in deficiency about the subject during diagnostic interventions and surgical procedures. Look forward to develop with extra anatomical data and clinical studies.

KARACAYLI, U. \& GOCMEN-MAS, N. Molares mandibulares anormales no-erupcionados múltiples: Reporte de un caso. Int. J. Morphol., 27(1):65-68, 2009.

RESUMEN: Los molares permanentes anormales no erupcionados múltiples, además de otras anomalías del desarrollo de los dientes, desde hace tiempo han recibido atención de anatomistas y cirujanos maxilofaciales. Este artículo presenta un caso clínico de un paciente masculino de 23 años de edad, que fue admitido en el Departamento de Cirugía Maxilofacial de la Facultad de Odontología de la Escuela de Medicina Gulhane, con una historia de seis meses de dolor, en la posición de descanso y durante la masticación, así como dolor en su cuerpo mandibular derecho. Fue encontrada la impactación que resulta de la falla en la erupción y la dislocación de la anatomía normal del desarrollo en tres molares mandibulares. En el examen extraoral fue definida asimetría facial del lado derecho. El diagnóstico de molares mandibulares anormales no erupcionados múltiples fue confirmado por radiografía panorámica e imágenes de tomografía 3D. El diente invertido no erupcionado fue el tercer molar que se encontró en la base de la mandíbula en el lado derecho. En el otro lado, el primer molar se posicionó sobre la base de la mandíbula distoangularmente. El segundo molar se encontró verticalmente en medio del cuerpo mandibular izquierdo. También, el tercer molar erupcionó mesioangularmente. La longitud del arco fue evaluada por el cirujano oral. La distancia mesio-distal entre los dientes fue suficiente. Las causas de impactación de los dientes permanentes podrían haber sido influenciadas por los factores locales, tales como la retención prolongada de dientes deciduos o gérmenes dentales malposicionados, pero no fueron provocados por deficiencia de longitud del arco y dientes supernumerarios. Anomalías tales como las reportadas en el presente caso, son importantes en la cirugía maxilofacial.

PALABRAS CLAVE: Molares malposicionados; Dientes permanentes; No erupción; Anormalidad.

\section{REFERENCES}

Ahlqwist, M. \& Gröndahl, H. G. Prevalence of impacted teeth and associated pathology in middle-aged and older Swidish women. Community Dent. Oral Epidemiol., 19(2):116-9, 1991.

Hayashi-Sakai, S.; Taguchi, Y. \& Noda, T. Failure of tooth eruption involving a mandibular primary first molar: a case report. J. Dent. Child. (Chic), 72(1):16-20, 2005.

Jacoby, H. The etiology of maxillary canine impactions. Am. J. Orthod., 84:(2):125-32, 1983.

Miloro, M. Peterson's Principals of Oral and Maxillofacial Surgery. $2^{\text {nd }}$ ed. Management of Impacted Teeth Other than Third Molars, London, B. C Decker Inc., 2004. pp.131-7.

Moyres, R. E. Handbook of orthodontics. $4^{\text {th }}$ ed. Chicago. Year Book Medical Publishers, 1988. p.387.

Ostuka, Y.; Mitomi, T.; Tomizawa, M. \& Noda, T. A review of clinical features in 13 cases of impacted primary teeth. Int. J. Paediatr. Dent., 11(1):57-63, 2001.

Raghoebar, G. M.; Boering, G.; Vissink, A. \& Stegenga, B. Eruption disturbances of permanent molars: a review. J. Oral Pathol. Med., 20(4):159-66, 1991.
Raghoebar, G. M.; van Koldam, W. A. \& Boering, G. Spontaneous reeruption of a secondarily retained permanent lower molar and an unusual migration of a lower third molar. Am. J. Orthod. Dentofacial. Orthop., 97(1):82-4, 1990.

Thilander, B. \& Myrberg, N. The prevalance of malocclusion in Swedish schoolchildren. Scand. J. Dent. Res., 81:(1)12-21, 1973.

Williams, P. L.; Bannister, L. H.; Berry, M. M.; Collins, P.; Dyson, M.; Dussek, J. E. \& Ferguson, M. W. J. Gray's Anatomy. Alimentary system. Section ed: Bannister, L. H. 38th ed. London, Churchill-Livingstone, 1995. pp.1700-18.

Correspondence to:

Nuket Gocmen-Mas

Umit Karacayli,DDS. PhD

Asag ıeg lence Sarayköy Sokak No 7/17

Etlik-Ankara/Turkey

Tel: +903123046043

Fax: +90 3123046020

E-mail: ukaracayli@gmail.com ukaracayli@gata.edu.tr

Received: 11-07-2008

Accepted: 10-10-2008 